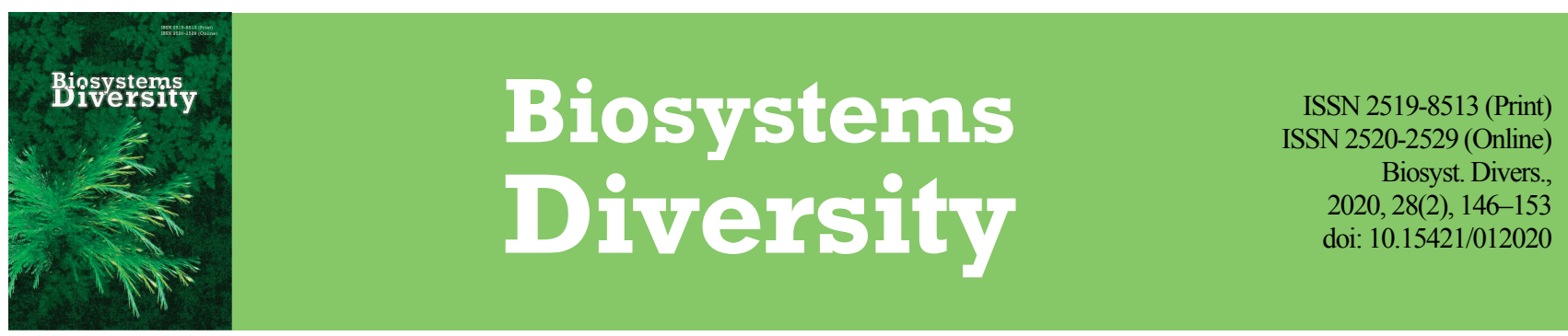

\title{
Dynamics of indices of metabolism in muscle tissue, liver and gonads of Abramis brama in different periods of the annual cycle
}

\author{
A. A. Payuta*, E. A. Flerova** \\ P. G. Demidov Yaroslavl State University, Yaroslavl, Russia
}

Article info

Received 21.04.2020

Received in revised form

13.05.2020

Accepted 14.05.2020

P. G. Demidov

Yaroslavl State

University,

Sovetskaya st., 14 ,

Yaroslavl,

150003, Russia

Tel.: 48-52-797-702.

E-mail:

rectorat@uniyar.ac.ru
Payuta, A. A., \& Flerova, E. A. (2020). Dynamics of indices of metabolism in muscle tissue, liver and gonads of Abramis brama in different periods of the annual cycle. Biosystems Diversity, 28(2), 146-153. doi:10.15421/012020

The aim of this research was to study the dynamics of metabolism in the body of bream Abramis brama (L.) at different periods of the annual cycle: pre-spawning, spawning, post-spawning and feeding. The object of the study was 55 male and 53 female bream aged 9-13 years, to reduce the effect of age on the studied parameters. Individuals were measured, weighed, gender was determined, gonad maturity stage, age; the condition factor and organ indices were calculated. The content of moisture, dry matter, lipids, proteins, ash and nitrogen-free extracts (NFE) in the muscles, liver and gonads of male and female bream have been analyzed. The lowest coefficients of condition factor were found in bream during the autumn feeding season, the highest in males during spawning, in females before and after spawning. In the muscle tissue of male and female bream the content of metabolic products in the feeding period and before spawning differed slightly. In the spawning period, the muscles of males exceeded the muscle tissue of females in lipid content by more than two times. In the annual cycle of the bream, the ovaries contain more protein than the testes. The bream of different sex revealed differences in the intensity of metabolic processes during the maturation of gonads: in males, energy costs are more pronounced after wintering before spawning, while in females, during spawning. The main energy reserve in the form of lipids in the annual cycle changes more significantly in the body of male bream than in females. Ovarian maturation requires more metabolite reserves than maturation of the testes, however, males have increased expenditure associated with reproductive behaviour during spawning. Therefore, the total energy contribution to reproduction may be the same for female and for male bream. Bream's liver and muscle tissue can serve as a source of energy during food shortages and during spawning. In the annual cycle, the condition factor of bream increases due to an increase in the moisture content in the muscles.

Keywords: bream; sex; gonad maturity; condition factor; spawning.

\section{Introduction}

Over the course of a year, populations of animals, including fish, undergo qualitatively different specific stable states called the periods of the annual cycle, which start depending on the environmental factors (length of daylight hours, temperature, dry or wet season) (Shulman \& Love, 1999; Wootton \& Smith, 2015; Marenkov, 2018; Soyano \& Mushirobira, 2018). Maturation of the gonads and spawning, which is considered the last stage of the biological cycle, are a complex process closely related to metabolism, which cause significant changes in the biochemical composition of fish (Grande et al., 2016; Khalko, 2018). After spawning, hydrobionts begin their new annual cycle, during which the individuals restore their regenerative functions and nutrients accumulate in the organism (Jan et al., 2012; Varkentin, 2015).

In the process of distribution of the energy in the body of fish in different periods of the annual cycle, fats, proteins, mineral substances and other components perform various functions (Bilokon et al., 2013; Zarubin et al., 2013; do Carmo Silva et al., 2019). Therefore, lipids play an important role for the health and reproduction of the individuals and survivability of the progeny (Lloret et al., 2014; Hiraoka et al., 2019; Zorica et al., 2019). The process of maturation of the gonads of hydrobionts is associated with the synthesis of protein (Carter \& Houlihan, 2001). Mineral substances are necessary for the reproduction and energy metabolism of animals (Kumar et al., 2019). Therefore, during the evaluation of physiological condition of fish in different periods of the annual cycle, it is important to have data on the dynamics of the content of the metabolism products in the muscles and the organs. The study of the biochemical changes in the organism of hydrobionts in the pre-spawning and spawning periods allows more complete revelation of the process of reproduction and also prediction of the terms and duration of the spawning, and therefore the productivity of individuals (Krivobok \& Tarkovskaya, 1960; Rajasilta, 1992). The literature mostly reveals the seasonal changes in the parameters of metabolism of marine fish (Gorbatenko \& Lazhentsev, 2016; Romotowska et al., 2016; John Kiran et al., 2017; Kosker et al., 2018; Hossain et al., 2019). However, there is a small number of more complete studies for the freshwater fish and these focus on the dynamics of certain parameters of metabolism in some organs (Craig, 1977; Pradhan et al., 2015; Petenuci et al., 2016). Among different systematic groups of freshwater fishes, a large share comprises the representatives of the Cypriniformes order. Among Cypriniformes, common bream Abramis brama (L.) are one of the most numerous industrial fish of freshwater water bodies and have an important place in the structure of their ecosystems (Kostić et al., 2016; Karabanov et al., 2018; Brodersen et al., 2019; Ding et al., 2019; Žák et al., 2019). The dynamics of accumulation of products of metabolism in the organism of common bream in different periods of annual cycle require separate and comprehensive analysis.

The objective of our study was the dynamics of the parameters of metabolism in the muscle tissue, liver and gonads of fresh-water fish on the example of common bream in different periods of the life cycle.

\section{Material and methods}

The object of the studies was individuals of bream from the Rybinsk Reservoir - the largest freshwater body in Russia of lake type with high fishery importance (Mikryakov et al., 2013). Bream were studied in different periods of the annual cycle (pre-spawning, spawning, post-spawning and feeding periods), which correspond to different physiological conditions of individuals. The material was made up of samples of the muscular tissue, liver and gonads. The individuals were caught by seine fishing at the checkpoint Krasny Ruchei (the Volga stretch of the Rybinsk 
Reservoir) in the spring-summer period (March - June) and trawling in the feeding period (late September - early October) at the standard trawling stations of the Rybinsk Reservoir. The muscles and the organs were extracted from 55 male and 53 female bream aged $9+$ to $13+$ to minimise changes in the content of metabolic products related to the age of the fish (Table 1).

Table 1

Size and mass of bream in different periods of the annual cycle $(x \pm S E)$

\begin{tabular}{|c|c|c|c|c|c|c|c|}
\hline Sex & $\begin{array}{l}\text { Maturity } \\
\text { stage of } \\
\text { the } \\
\text { gonads }\end{array}$ & Period & $\begin{array}{l}\text { Time of } \\
\text { capture }\end{array}$ & $\mathrm{n}$ & $\begin{array}{l}\text { Length } \\
(S L), \mathrm{cm}\end{array}$ & Weight, g & $\begin{array}{c}\text { Weight } \\
\text { of fish } \\
\text { without } \\
\text { internal } \\
\text { organs, g }\end{array}$ \\
\hline \multirow{4}{*}{ Males } & III & $\begin{array}{l}\text { Before } \\
\text { spawning }\end{array}$ & $\begin{array}{l}\text { March, } \\
\text { April }\end{array}$ & 12 & $35.5 \pm 0.8$ & $1003 \pm 45$ & $890 \pm 52$ \\
\hline & IV & Spawning & May & 12 & $38.5 \pm 0.6$ & $1271 \pm 36$ & $1153 \pm 35$ \\
\hline & VI & $\begin{array}{l}\text { After } \\
\text { spawning }\end{array}$ & $\begin{array}{l}\text { May, } \\
\text { June }\end{array}$ & 12 & $37.6 \pm 0.6$ & $1201 \pm 64$ & $1095 \pm 57$ \\
\hline & III & Feeding & September & 19 & $36.8 \pm 0.4$ & $840 \pm 42$ & $776 \pm 30$ \\
\hline \multirow{4}{*}{ Females } & III & $\begin{array}{l}\text { Before } \\
\text { spawning }\end{array}$ & $\begin{array}{l}\text { March, } \\
\text { April }\end{array}$ & 12 & $37.6 \pm 0.5$ & $1198 \pm 40$ & $1022 \pm 37$ \\
\hline & IV & Spawning & May & 12 & $38.9 \pm 0.5$ & $1191 \pm 76$ & $1070 \pm 61$ \\
\hline & VI & $\begin{array}{l}\text { After } \\
\text { spawning }\end{array}$ & $\begin{array}{l}\text { May, } \\
\text { June }\end{array}$ & 12 & $38.6 \pm 0.9$ & $1239 \pm 67$ & $1129 \pm 58$ \\
\hline & III & Feeding & September & 17 & $37.2 \pm 0.5$ & $916 \pm 36$ & $801 \pm 31$ \\
\hline
\end{tabular}

After the fish were caught, they underwent acclimation in containers with river water. Then, for each individual we determined standard length (SL), mass (total and with no internal organs), sex and the maturity stage of the gonads according to the generally accepted methods (Pravdin, 1966). Afterwards, on the refrigerant the skin was removed from the skeletal muscles, the muscular tissue was excised along the vertebral column, the liver and the gonads were removed from the internal cavity, the samples were weighed and frozen until the analysis. The age of the fish was determined according to the zones of growth on the scales.

To determine the amount of the total moisture and the dry matter, we used the two-stage method of determining moisture. The amount of free water in the muscular tissue and the organs was obtained by drying the weighed amounts at the temperature of $60{ }^{\circ} \mathrm{C}$ to their constant weight. Then, the sample was fragmented in the laboratory grinder and dried at the temperature of $105{ }^{\circ} \mathrm{C}$ to the constant mass of the weighed amount. The amount of the total moisture and dry matter was determined using different methods (Flerova, 2014).

The amount of crude protein was determined using the Kjeldahl method. The obtained percentage amount of nitrogen in the sample was multiplied by empiric coefficient of the adjustment of protein equaling 6.25 and the parameter of humid protein was determined as the sum of different nitrogenous substances based on proteins (Yeganeh, 2012; Flerova, 2014).

The amount of fat in the muscular tissue was determined using the method of defatted residue in the Soxhlet's apparatus. The extraction was conducted using non-polar solvent - petroleum benzene (Flerova, 2014). Crude fat obtained in such way is mainly composed of fats (triacylglycerols), and also small amount of other lipids (phospholipids, steroids, carotenoids, fat-soluble vitamins and others). Non-polar lipids obtained using decomposition of the van der Waals interaction of lipids with proteins and other substances in the cell by ether are mostly the reserve energy elements (Parrish, 1999).

The mineral substances were obtained using gravimetric method of burning off the weighed amount in the muffle furnace to the white-coloured ash at a temperature of $550{ }^{\circ} \mathrm{C}$ (Flerova, 2014). The amount of nitrogen-free extracts was determined by substracting the sum of percents of the total water, crude protein, crude fat, ash from the $100 \%$ (Flerova, 2014).

Gonadosomatic index was determined as the ratio of the mass of gonads to the body weight, expressed as a percentage, hepatosomatic index as the ratio of the mass of liver to the body weight, expressed as a percentage. Fatness coefficient according to Fulton was determined according to the formula $F c_{(F)}=w \cdot 100 / l^{3}$, in which $F c_{(F)}$ is the fatness coefficient according to Fulton, $w$ - weight of fish in grams, $l$ - body length of fish in $\mathrm{cm}$. Fatness coefficient according to Clark was determined using the formula $F c_{(C)}=w_{l} \cdot 100 / l^{3}$, where $F c_{(C)}$ - fatness coefficient according to Clark, $w_{l}$-weight of test tube in grams, $l$-body length of fish in $\mathrm{cm}$.

The data were statistically analyzed using Statistica software. The data are presented as mean values and their standard errors $(x \pm S E)$. The differences between the values in different periods of the annual cycle were determined using ANOVA using the Bonferroni correction. The differences between the compared parameters were statistically significant at $\mathrm{P}<0.05$.

\section{Results}

The lowest fatness coefficients were observed in bream during the autumn feeding, the highest in males - during spawning, in females - before the spawning according to Fulton, and in the post-spawning period according to Clark (Table 2).

\section{Table 2}

Fatness and the indices of the organs of bream in different periods of the annual cycle $(\mathrm{x} \pm \mathrm{SE})$

\begin{tabular}{|c|c|c|c|c|c|c|}
\hline \multirow[b]{2}{*}{ Sex } & \multirow{2}{*}{$\begin{array}{l}\text { Time of capture, } \\
\text { stage of the } \\
\text { maturity of the } \\
\text { gonads }\end{array}$} & \multirow[b]{2}{*}{$\mathrm{n}$} & \multicolumn{2}{|c|}{ Fatness coefficient } & \multirow[b]{2}{*}{$\begin{array}{l}\text { Gonado- } \\
\text { somatic } \\
\text { index }\end{array}$} & \multirow[b]{2}{*}{$\begin{array}{c}\text { Hepato- } \\
\text { somatic } \\
\text { index }\end{array}$} \\
\hline & & & $\begin{array}{l}\text { accor } \\
\text { to } \mathrm{Fu}\end{array}$ & $\begin{array}{l}\text { acce } \\
\text { to }\end{array}$ & & \\
\hline \multirow{4}{*}{ Males } & Marcl & 12 & & & & \\
\hline & $\mathrm{Ma}$ & 12 & & & & \\
\hline & May & 12 & $2.25 \pm$ & 2.05 & & \\
\hline & & 19 & & 1. & & \\
\hline \multirow{4}{*}{$\begin{array}{c}\text { Fema- } \\
\text { les }\end{array}$} & Mar & 12 & $2.26 \pm 0.02^{\mathrm{a}}$ & $1.93 \pm 0.02^{\mathrm{a}}$ & & \\
\hline & $\mathrm{Ma}$ & 12 & $2.01 \pm 0.05^{\mathrm{ab}}$ & $1.81 \pm 0.04^{\mathrm{ab}}$ & 3.5 & \\
\hline & May & 12 & 2.16 & 1.9 & 1.5 & $.11^{\mathrm{a}}$ \\
\hline & Septer & 17 & $1.77 \pm 0.03^{\mathrm{b}}$ & $0.03^{\mathrm{b}}$ & 1.3 & 1.1 \\
\hline
\end{tabular}

Note: different letters in the column indicate values which are statistically different between each other between the periods of the annual cycle separately for females and males using the Bonferroni correction $(\mathrm{P}<0.05)$.

On average, before the spawning, in the muscular tissue of bream of different sexes, the content of products of metabolism was similar, whereas in the spawning period, the muscles of males had higher content of lipids and protein than the muscular tissue of females, and had double the females' content of fat reserves (Fig. 1). After the spawning, in the muscular tissue of females, the share of protein, ash and nitrogen-free extracts accumulated more intensively than in males, and over the feeding period the content of metabolites in the individuals of different sexes varied insignificantly.

During each period, the liver of females differed by the heightened content of the dry matter and lipids, except in the pre-spawning period (Fig. 2). After the spawning and in the feeding period, the liver of males accumulated a larger amount of protein and mineral substances compared with the females. During the annual cycle, the testes were characterized by high content of lipids, whereas the ovaries had high content of protein and ash, and also nitrogen-free extracts (except post-spawning period, Fig. 3).

In the pre-spawning period (March - April), the muscular tissue of males was characterized by the lowest content of lipids and protein, whereas the liver was characterized by low values of these parameters compared with the feeding period. Before the spawning, the testes contained the highest amount of protein and ash and average amount of lipids (Table 3). The indices of the organs increased compared with the period of feeding (Table 2). During the spawning, in the muscles of males, the amount of lipids and protein accumulated, the carbohydrate part was expended. In the liver and gonads in that period, the total amount of the products of metabolism significantly decreased and their water content increased, accompanied with increase in the indices of the organs (Tables 2,3).

After the spawning, the content of the products of metabolism decreased in the muscles of males, and significantly increased in the liver and gonads. In that period, in the liver, the largest amount of lipids and protein accumulated. In the testes, the share of macronutrients increased, whereas the content of lipids increased by over 6 times compared with the previous period (Table 3). Despite the increase in the amount of metabolites in the organs after the spawning, the hepatosomatic index, and chiefly the gonadosomatic index significantly decreased (Table 2 ). 


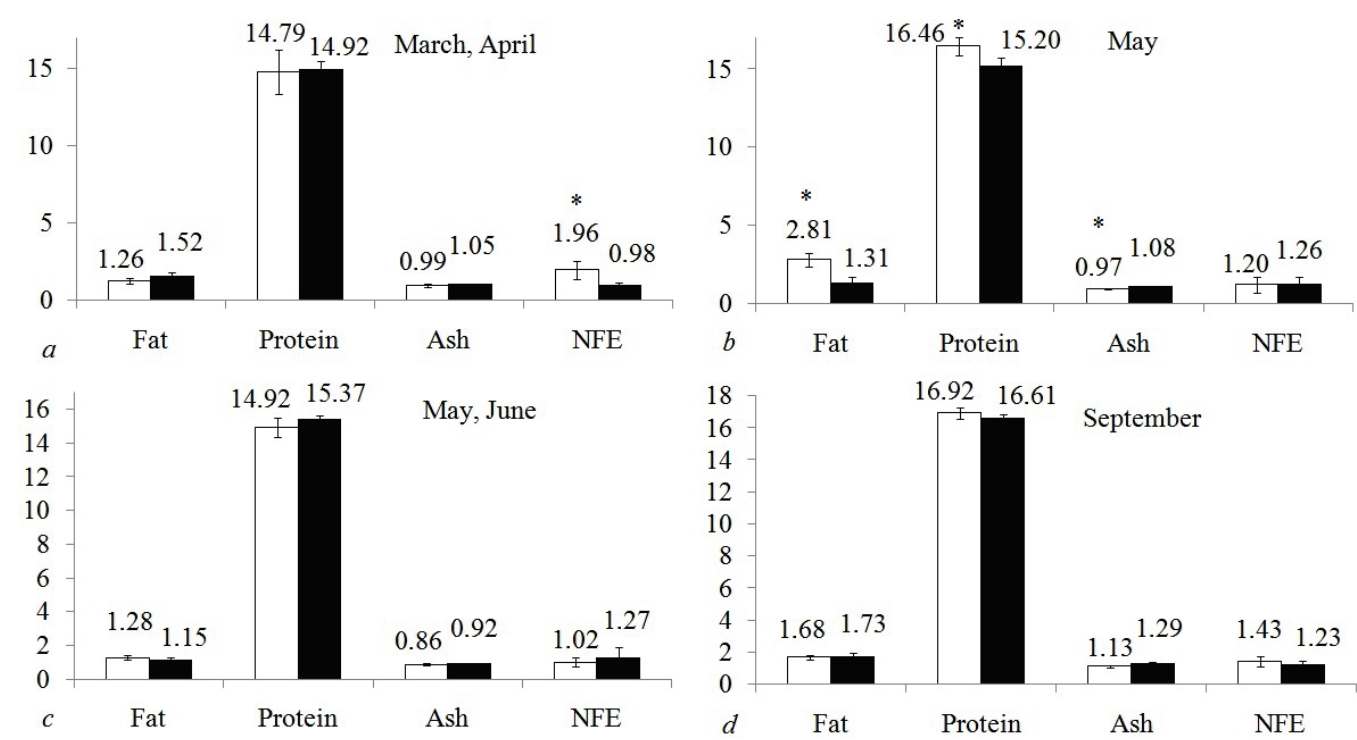

Fig. 1. Chemical composition (\%) of the muscles of bream of different sexes before the spawning $(a)$, during the spawning $(b)$, after the spawning $(c)$, in the feeding periods $(d)$; white columns - males, black - females; $x \pm S E, n=12$, in the feeding period of males $n=19$, females $n=17$;

$*$-reliable difference compared with the females $(\mathrm{P}<0.05)$

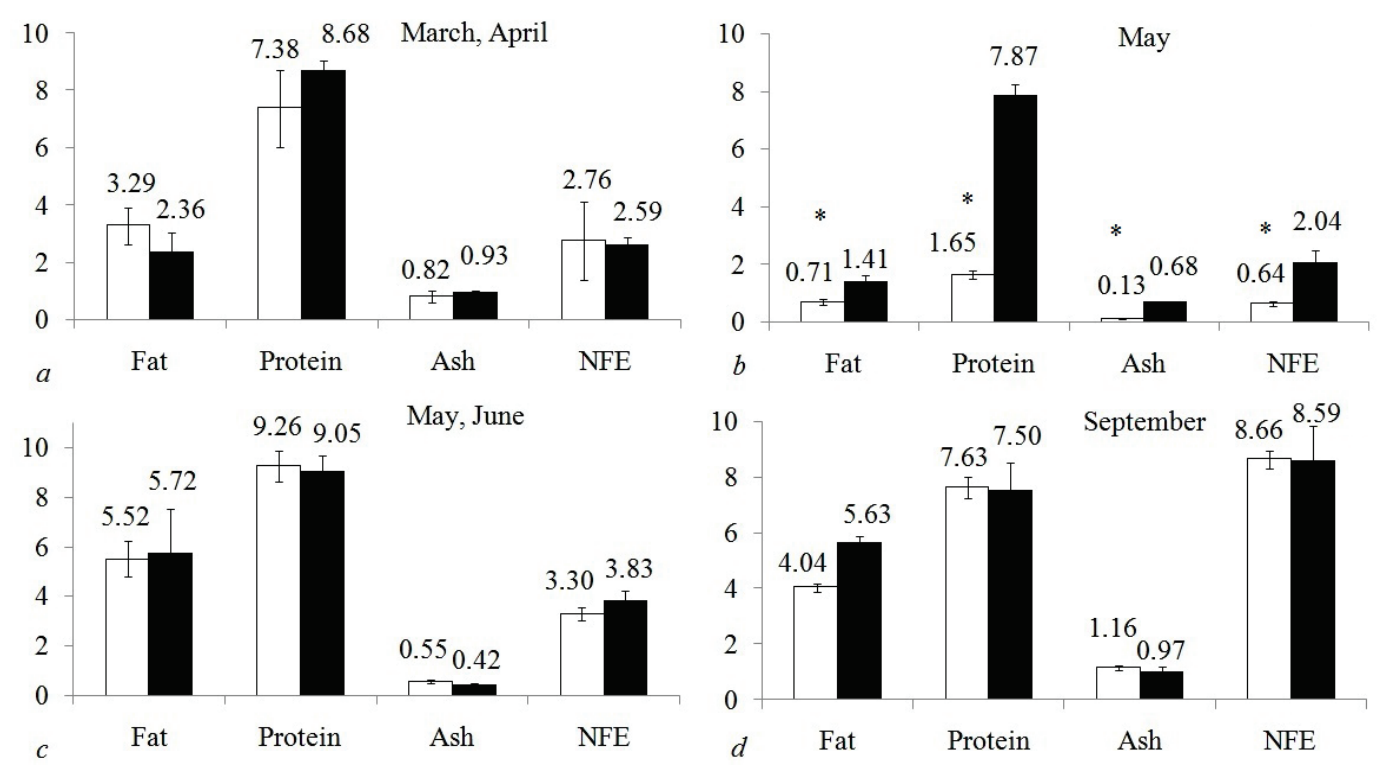

Fig. 2. Chemical composition (\%) of the liver of bream of different sexes before the spawning $(a)$, during the spawning $(b)$, after the spawning $(c)$, in the feeding period $(d)$; see Fig. 1
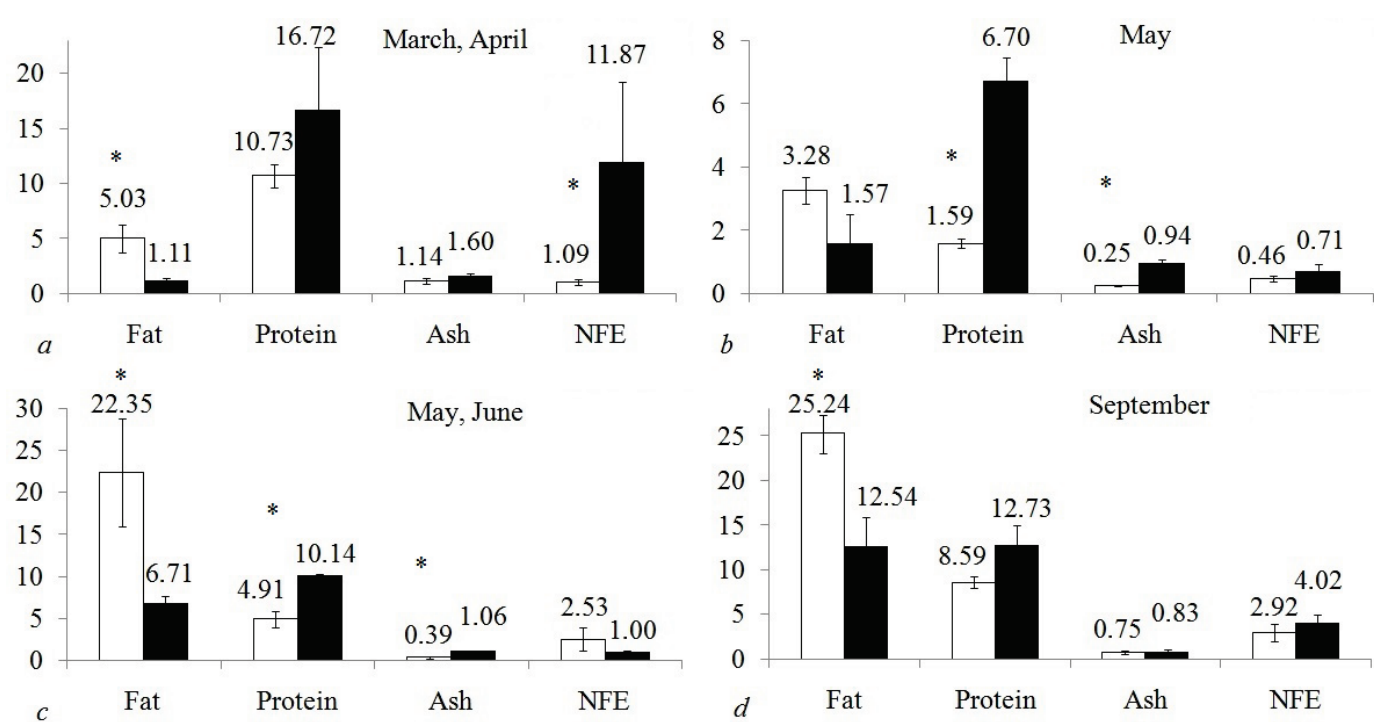

Fig. 3. Chemical composition (\%) of the gonads of bream of different sexes before the spawning $(a)$ during the spawning $(b)$, after the spawning $(c)$, in the feeding period $(d)$; see Fig. 1 
Table 3

Chemical composition of the muscles, liver and the gonads of bream in the different periods of the annual cycle $(\mathrm{x} \pm \mathrm{SE})$

\begin{tabular}{|c|c|c|c|c|c|c|c|c|}
\hline $\begin{array}{l}\text { The tissue, } \\
\text { organ }\end{array}$ & $\begin{array}{l}\text { Time of capture, stage } \\
\text { of the maturity of the gonads }\end{array}$ & $\mathrm{n}$ & Total moisture, \% & Dry matter, \% & Fat, \% & Protein, $\%$ & Ash, \% & Nitrogen-free extracts, $\%$ \\
\hline \multirow{4}{*}{$\begin{array}{l}\text { The muscular } \\
\text { tissue }\end{array}$} & March-April, III & 12 & $81.01 \pm 0.94^{\mathrm{ab}}$ & $18.99 \pm 0.94^{\mathrm{ab}}$ & $1.26 \pm 0.18^{\mathrm{a}}$ & $14.79 \pm 1.45^{\mathrm{a}}$ & $0.99 \pm 0.11^{\mathrm{a}}$ & $1.96 \pm 0.60^{\mathrm{a}}$ \\
\hline & May, IV & 12 & $78.56 \pm 0.52^{\mathrm{a}}$ & $21.44 \pm 0.52^{\mathrm{a}}$ & $2.81 \pm 0.42^{\mathrm{b}}$ & $16.46 \pm 0.61^{\mathrm{a}}$ & $0.97 \pm 0.04^{\mathrm{a}}$ & $1.20 \pm 0.48^{\mathrm{a}}$ \\
\hline & May-June, VI & 12 & $81.93 \pm 0.56^{b}$ & $18.07 \pm 0.56^{\mathrm{b}}$ & $1.28 \pm 0.12^{\mathrm{a}}$ & $14.92 \pm 0.56^{\mathrm{a}}$ & $0.86 \pm 0.06^{\mathrm{a}}$ & $1.02 \pm 0.27^{\mathrm{a}}$ \\
\hline & September, III & 19 & $78.84 \pm 0.28^{\mathrm{a}}$ & $21.16 \pm 0.28^{\mathrm{a}}$ & $1.68 \pm 0.14^{\text {ab }}$ & $16.92 \pm 0.38^{\mathrm{a}}$ & $1.13 \pm 0.09^{\mathrm{a}}$ & $1.43 \pm 0.32^{\mathrm{a}}$ \\
\hline \multirow{4}{*}{ The liver } & March - April, III & 12 & $85.76 \pm 2.49^{\mathrm{ab}}$ & $14.24 \pm 2.49^{\mathrm{ab}}$ & $3.29 \pm 0.64^{\mathrm{ab}}$ & $7.38 \pm 1.34^{\mathrm{ab}}$ & $0.82 \pm 0.19^{\mathrm{a}}$ & $2.76 \pm 1.36^{\mathrm{ab}}$ \\
\hline & May, IV & 12 & $96.87 \pm 0.17^{\mathrm{a}}$ & $3.13 \pm 0.17^{\mathrm{a}}$ & $0.71 \pm 0.11^{\mathrm{a}}$ & $1.65 \pm 0.16^{\mathrm{a}}$ & $0.13 \pm 0.01^{\mathrm{b}}$ & $0.64 \pm 0.08^{\mathrm{a}}$ \\
\hline & May-June, VI & 12 & $81.37 \pm 1.13^{\text {ab }}$ & $18.63 \pm 1.13^{\mathrm{ab}}$ & $5.52 \pm 0.72^{\mathrm{b}}$ & $9.26 \pm 0.62^{\mathrm{b}}$ & $0.55 \pm 0.08^{\mathrm{ab}}$ & $3.30 \pm 0.25^{\mathrm{ab}}$ \\
\hline & September, III & 19 & $78.51 \pm 0.68^{\mathrm{b}}$ & $21.49 \pm 0.68^{b}$ & $4.04 \pm 0.27^{b}$ & $7.63 \pm 1.02^{\mathrm{ab}}$ & $1.16 \pm 0.24^{\mathrm{a}}$ & $8.66 \pm 1.27^{b}$ \\
\hline \multirow{4}{*}{ The gonads } & March-April, III & 12 & $82.01 \pm 2.60^{\mathrm{ab}}$ & $17.99 \pm 2.60^{\mathrm{ab}}$ & $5.03 \pm 1.28^{\mathrm{ab}}$ & $10.73 \pm 1.06^{\mathrm{a}}$ & $1.14 \pm 0.23^{\mathrm{a}}$ & $1.09 \pm 0.26^{\mathrm{ab}}$ \\
\hline & May, IV & 12 & $94.41 \pm 0.47^{\mathrm{a}}$ & $5.59 \pm 0.47^{\mathrm{a}}$ & $3.28 \pm 0.42^{\mathrm{a}}$ & $1.59 \pm 0.15^{\mathrm{b}}$ & $0.25 \pm 0.03^{\mathrm{a}}$ & $0.46 \pm 0.09^{\mathrm{a}}$ \\
\hline & May-June, VI & 12 & $69.83 \pm 8.22^{\mathrm{ab}}$ & $30.17 \pm 8.22^{a b}$ & $22.35 \pm 6.42^{\mathrm{ab}}$ & $4.91 \pm 0.98^{\mathrm{ab}}$ & $0.39 \pm 0.15^{\mathrm{a}}$ & $2.53 \pm 1.35^{\mathrm{ab}}$ \\
\hline & September, III & 19 & $62.51 \pm 2.14^{\mathrm{b}}$ & $37.49 \pm 2.14^{\mathrm{b}}$ & $25.24 \pm 2.15^{\mathrm{b}}$ & $8.59 \pm 0.64^{\mathrm{a}}$ & $0.75 \pm 0.17^{\mathrm{a}}$ & $2.92 \pm 0.98^{\mathrm{b}}$ \\
\hline
\end{tabular}

Note: different letters in the column indicate the values which significantly differed from each other for the periods of the annual cycle separately for the muscular tissue, the liver and the gonads using the Bonferroni correction $(\mathrm{P}<0.05)$.

During the feeding period, in the muscles of males, the fatness increased and the content of protein was maximum compared with the other periods of the annual cycle (Table 3 ). Repeated maturation of the testes, characterized by increase in gonadosomatic index and increase in the amount of lipids and protein, was accompanied by decrease in these metabolites in the liver and insignificant decrease in the hepatosomatic index (Table 2). It is worth noting that the highest content of the carbohydrate share both in the liver and the sex glands of bream was reached in the feeding period.
In the pre-spawning period, muscular tissue of female bream was characterized by reduced content of dry matter, including protein and nitrogen-free extracts, while the liver was characterized by lower values of lipids and carbohydrates, but increased amount of protein, compared with the feeding period (Table 4). The ovaries and the liver before the spawning reached the largest sizes. Over that period, the gonads of female breams contained the largest amount of the dry matter, including protein, ash and nitrogen-free extracts, and quantity of lipids was the lowest (Table 2).

Table 4

Chemical composition of the muscles, liver and gonads of bream in different periods of the annual cycle $(\mathrm{x} \pm \mathrm{SE})$

\begin{tabular}{|c|c|c|c|c|c|c|c|c|}
\hline $\begin{array}{c}\text { The tissue, } \\
\text { organ }\end{array}$ & $\begin{array}{l}\text { Time of capture, stage of ma- } \\
\text { turity of the gonads }\end{array}$ & $\mathrm{n}$ & Total moisture, $\%$ & Dry matter, $\%$ & Fat, \% & Protein, $\%$ & Ash, $\%$ & Nitrogen-free extracts, $\%$ \\
\hline \multirow{4}{*}{$\begin{array}{l}\text { The muscular } \\
\text { tissue }\end{array}$} & March-April, III & 12 & $81.53 \pm 0.68^{\mathrm{a}}$ & $18.47 \pm 0.68^{\mathrm{a}}$ & $1.52 \pm 0.28^{\mathrm{a}}$ & $14.92 \pm 0.59^{\mathrm{a}}$ & $1.05 \pm 0.03^{\mathrm{a}}$ & $0.98 \pm 0.20^{\mathrm{a}}$ \\
\hline & May, IV & 12 & $81.15 \pm 0.43^{\mathrm{ab}}$ & $18.85 \pm 0.43^{\mathrm{ab}}$ & $1.31 \pm 0.36^{\mathrm{a}}$ & $15.20 \pm 0.51^{\mathrm{ab}}$ & $1.08 \pm 0.04^{\mathrm{a}}$ & $1.26 \pm 0.42^{\mathrm{a}}$ \\
\hline & May-June, VI & 12 & $81.28 \pm 0.73^{\mathrm{ab}}$ & $18.72 \pm 0.73^{\mathrm{ab}}$ & $1.15 \pm 0.11^{\mathrm{a}}$ & $15.37 \pm 0.28^{\mathrm{ab}}$ & $0.92 \pm 0.05^{\mathrm{a}}$ & $1.27 \pm 0.59^{\mathrm{a}}$ \\
\hline & September, III & 17 & $79.14 \pm 0.41^{\mathrm{b}}$ & $20.86 \pm 0.41^{\mathrm{b}}$ & $1.73 \pm 0.22^{\mathrm{a}}$ & $16.61 \pm 0.26^{\mathrm{b}}$ & $1.29 \pm 0.11^{\mathrm{a}}$ & $1.23 \pm 0.21^{\mathrm{a}}$ \\
\hline \multirow{4}{*}{ The liver } & March-April, III & 12 & $85.44 \pm 0.59^{\mathrm{ab}}$ & $14.56 \pm 0.59^{\mathrm{ab}}$ & $2.36 \pm 0.69^{\mathrm{ab}}$ & $8.68 \pm 0.36^{\mathrm{a}}$ & $0.93 \pm 0.10^{\mathrm{a}}$ & $2.59 \pm 0.31^{\mathrm{a}}$ \\
\hline & May, IV & 12 & $87.99 \pm 0.48^{\mathrm{a}}$ & $12.01 \pm 0.48^{\mathrm{a}}$ & $1.41 \pm 0.22^{\mathrm{b}}$ & $7.87 \pm 0.36^{\mathrm{a}}$ & $0.68 \pm 0.04^{\mathrm{ab}}$ & $2.04 \pm 0.44^{\mathrm{a}}$ \\
\hline & May-June, VI & 12 & $80.99 \pm 1.74^{\mathrm{ab}}$ & $19.01 \pm 1.74^{\mathrm{ab}}$ & $5.72 \pm 1.80^{\mathrm{a}}$ & $9.05 \pm 0.63^{\mathrm{a}}$ & $0.42 \pm 0.05^{\mathrm{b}}$ & $3.83 \pm 0.42^{\mathrm{ab}}$ \\
\hline & September, III & 17 & $77.30 \pm 1.39^{b}$ & $22.70 \pm 1.39^{\mathrm{b}}$ & $5.63 \pm 0.73^{\mathrm{a}}$ & $7.50 \pm 0.85^{\mathrm{a}}$ & $0.97 \pm 0.11^{\mathrm{a}}$ & $8.59 \pm 0.94^{b}$ \\
\hline \multirow{4}{*}{ The gonads } & March-April, III & 12 & $68.70 \pm 3.41^{\mathrm{a}}$ & $31.30 \pm 3.41^{\mathrm{a}}$ & $1.11 \pm 0.32^{\mathrm{a}}$ & $16.72 \pm 5.63^{\mathrm{a}}$ & $1.60 \pm 0.25^{\mathrm{a}}$ & $11.87 \pm 7.35^{\mathrm{a}}$ \\
\hline & May, IV & 12 & $90.08 \pm 1.17^{b}$ & $9.92 \pm 1.17^{\mathrm{b}}$ & $1.57 \pm 0.94^{\mathrm{a}}$ & $6.70 \pm 0.79^{\mathrm{a}}$ & $0.94 \pm 0.14^{\mathrm{a}}$ & $0.71 \pm 0.23^{\mathrm{b}}$ \\
\hline & May - June, VI & 12 & $81.08 \pm 0.97^{\mathrm{ab}}$ & $18.92 \pm 0.97^{\mathrm{ab}}$ & $6.71 \pm 1.03^{\mathrm{ab}}$ & $10.14 \pm 0.16^{\mathrm{a}}$ & $1.06 \pm 0.10^{\mathrm{a}}$ & $1.00 \pm 0.22^{\mathrm{ab}}$ \\
\hline & September, III & 17 & $69.88 \pm 2.34^{\mathrm{a}}$ & $30.12 \pm 2.34^{\mathrm{a}}$ & $12.54 \pm 3.35^{\mathrm{b}}$ & $12.73 \pm 2.21^{\mathrm{a}}$ & $0.83 \pm 0.23^{\mathrm{a}}$ & $4.02 \pm 0.95^{\mathrm{ab}}$ \\
\hline
\end{tabular}

Note: see Table 3

During the spawning, in the muscular tissue of females, the content of lipids decreased, whereas protein, ash and nitrogen-free extracts insignificantly increased (Table 4). Decrease in the indices of the organs was accompanied by depletion of the reserves of protein, mineral substances and the carbohydrate share and increase in the share of moisture, nonetheless, the quantitative changes in the chemical composition in the females were less intense than in the males (Tables 2-4). Furthermore, the content of lipids decreased in the liver, and increased in the gonads.

After the spawning, in the muscles of females, the content of the total moisture, protein and nitrogen-free extracts insignificantly increased, while the quantity of lipids and ash decreased (Table 4). Despite the fact that this period was characterized by decrease in the gonadosomatic index and slight increase in the hepatosomatic index, the share of dry matter, lipids, protein and nitrogen-free extracts increased both in the liver and the gonads (Tables 2, 4). During the feeding period, the highest contents of lipids, proteins and mineral substances was seen in the muscular tissue of female bream, ash and nitrogen-free extracts in the liver, and lipids in the gonads (Table 4). Maturation of the ovaries was accompanied by the accumulation of protein and carbohydrate in them and the expenditure of the reserves of fat and protein from the liver, while the indices of the organs of the individuals decreased (Tables 2, 4).

\section{Discussion}

Bream belongs to fish with no sharply manifested portion spawn. Spawning of one individual can occur in several attempts during a number of days. In the water bodies of the Upper Volga, spawning of bream occurs mostly at the same time, nonetheless there are individuals with nonsimultaneous maturation of oocytes (German, 2019). The comparison of the contents of the products of metabolism in the bodies of male and female bream in different periods of the annual cycle revealed some peculiarities. Therefore, differences in the contents of the parameters of the metabolism in the individuals of bream of different sexes were more significant in the organs than in the muscular tissue. Heightened content of lipids in the muscular tissue of males during spawning, compared to females, could indicate lower expenditures of metabolites during production of lower amount of gonadal products than in females, leading to accumulation of fat reserves in the body of males and their better preparedness for spawning (Shulman \& Love, 1999). The first presumption is confirmed by the higher content of fat in the muscles of males in the post-spawning period, indicating lower exhaustion of the organism of males than females. A number of studies report greater energy expenditures in the organism of fish for the development of the ovaries than the testes (Diana \& MacKay, 1979; Adams et al., 1982; Wootton, 1985). Perhaps, due to this reason, the gonads of female bream exceeded the gonads of males in content of protein. Earlier, we demonstrated that in the ovaries of zander Sander lucioperca (L.) and ziege Pelecus cultratus (L.), the protein accumulated more intensely than in the testes (Payuta \& Flerova, 2019). Similar results were seen in Scatophagus argus (L.) and Liza haematocheilus (Temminck, Schlegel) (Venkatesan et al., 2013; Kornienko et al., 2017). It should be noted that in the process of maturation of the gonads, the biochemical composition of the muscles and the organs of female bream was characte- 
rized by greater stability than the males. In the pre-spawning period, the muscular tissue of male bream was seen to have the lowest amount of lipids and protein for the entire annual cycle, while the muscular tissue of females had the lowest amount of the dry matters, including protein (Tables 3, 4).

Compared to the period of the feeding (September), the content of lipids in the muscles and the organs of bream decreased, while the amount of protein in the gonads increased. Increase in the mineral substances in the gonads before the spawning was accompanied by fall in the ash content in the muscles and the liver. Redistribution of the share of nutrients in the organism of the surveyed fish was accompanied by the increase in the gonadosomatic index (Table 2). Decrease in the main products of metabolism in the muscles of the fish could occur due to the exhaustion of the individuals after winter starvation, as wells as expenditure of energy for the maturation of the gonads and preparation to spawning (Medford \& Mackay, 1978; Wallace \& Selman, 1981; Jøsrgensen et al., 1997; Grigorakis et al., 2002). By the end of the pre-spawning period, proteins and lipids in the body of fish are expended for trophoplasmatic growth of oocytes and the development of spermatogonia, when they accumulate nutrients, and the gonads, especially the ovaries, increases in size (Shankar \& Kulkarni, 2006; Tyheev \& Tomitova, 2016; Komova et al., 2017). Fish with low quantity of lipids in the muscles (thin), to which bream belongs, after winter starvation mobilize protein as endogenous energy source, and the exhaustion of the energy resources in the body of hydrobionts leads to general decrease in their condition (Shatunovskii, 1980; Yeannes \& Almandos, 2003; Zaboukas et al., 2006). The muscular tissue is likely to be the main "depot" for the products of mineral metabolism necessary for the maturation of the gonads in male and female bream (Rao \& Krishnan, 2011).

During the spawning, in the muscles of individuals of bream, an increase in the share of protein was seen (Table 3, 4). Moreover, in male bream, the content of lipids increased and the share of carbohydrates decreased, while the females were observed to have reverse dynamics. In the liver, metabolic processes in both sexes took their course in one direction, but with different intensity: the content of metabolites decreased, and in males the values of the parameters were the highest during the entire annual cycle. In the gonads of bream, in this period, the amount of metabolic products decreased, except lipids, the content of which insignificantly increased in the ovaries (Tables 3, 4). Since the early spring, in the prespawning period, the Cyprinidae begin to feed actively, perhaps, because of this, by the moment of spawning, in the muscular tissue of bream, accumulation of protein was observed (Komova et al., 2017). In addition, the decrease in the expenditure of protein in the muscles of female bream could occur due to use of fat reserves (Shatunovskii, 1980). In the muscular tissue of females of Teleostei, including Cyprinidae, during spawning, decrease in lipids was seen (Wallace \& Selman, 1981; Guijarro et al., 2003). The main expenditure of carbohydrates in the organism of male bream in this period is probably associated with the reproductive behaviour regulated by hormones: individuals become aggressive and their moving activity increases (Diamond, 1985; Zaboukas et al., 2006; Matondo et al., 2009; Munakataa \& Kobayashib, 2010; Poncin et al., 2011). For the gonadal products of fish, some part of proteins, further transported to the gonads of the serum blood, synthesizes directly in the liver (Plack et al., 1971). Perhaps that is why, during the spawning, the bream was observed to have decrease in protein in the liver. The amount of protein in the gonads of bream can decrease due to the release of gonadal products composed chiefly of protein (Islam \& Joadder, 2005; Jan et al., 2012). Moreover, decrease in protein in the ovaries of fish occurs due to hydrolysis and reduction of the dry matter of oocytes, as a result of which, water and non-organic ions intensively penetrates the cell, thus contributing to the oxidation of fatty acids and facilitating spawning. At the same time, lipids mobilized from the organism and transported into the sex glands of females, and also moisture provides low density and floating ability of eggs (Wootton, 1974; Shreni, 1980; Sutharshiny et al., 2013; Lloret et al., 2014). Mass of the gonads, and therefore the gonadosomatic index, increased due to the hydration of water in eggs (Table 2).

After the spawning, in the muscles of bream, the amount of dry matter reduced, including lipids and ash (Table 4). The content of protein in the muscular tissue decreased in males, and insignificantly increased in females. In the liver and the gonads of individuals of bream of both sexes, a decrease was observed in the total moisture, increase in lipids, proteins and nitrogen-free extractive substances. Different content of products of metabolism in the muscles and organs of males and females of bream during the post-spawning period shows the extent of exhaustion of the organism of individuals of different sexes after reproduction and rates of its recovery since the beginning of feeding (Table 3, 4). Decrease in the content of fat and protein in the body of hydrobionts after the spawning was seen in other studies focused on the accumulation of products of metabolism in different stages of the life cycle in freshwater fish (Somvansh, 1983; Dabhade et al., 2009). Accumulation of protein in the muscles of female bream is perhaps associated with the fact that after depositing eggs they move away from the spawning grounds and start feeding right away, while some part of the producers remains in the shallow-water areas (Ilmast, 2005). Decrease in the amount of nitrogen-free extracts in the muscular tissue of males suggests their high moving activity in this period.

Notable increase in the content of lipids, protein and carbohydrate in the liver of bream, accompanied by fall in hepatosomatic and gonadosomatic indices, in the post-spawning period (Tables 2-4) could be attributed to the completion of spawning (Shankar \& Kulkarni, 2006; Grande et al., 2016). Earlier, there was reported immediate increase in lipids in the liver of freshwater fish right after the spawning related to their active feeding (Shreni, 1980; Kozlova, 1997). Replenishment of the energy reserves in the liver of bream is likely associated with the fact that the gonads in that period are in the stage of rest and food consumed by the fish could be used for accumulation of products of metabolism (Islam \& Joadder, 2005; Jan et al., 2012; Smith \& Wootton, 2015). In spring, in male bream in the Volga, maturation occurs of only a part of cysts - accumulation of spermatogonia under one membrane, the rest complete the maturation in the process of reproduction, which leads to prolongation of the process of spermatogenesis and sperm release to $1.0-1.5$ months. Individuals can continue to produce milt after spawning and loss of breeding dress (Turdakov, 1972). Perhaps, high values of parameters of lipids and protein in the testes of bream from the Rybinsk Reservoir in May and June could be associated with this fact. In the bream populations from the Rybinsk Reservoir, there occur females with disorder of synchronous development of oocytes, related to the abnormally high average daily temperature of water. For this reason, in individuals, the second portion of eggs forms, which maturates incompletely and with time dissolves (German, 2019). In Cyprinidae, a significant percent of lipids accumulates not only in the gonadal cells particularly, but also in intercellular tissues and is used as an energy "depot" for the processes associated with the generative synthesis (Shulman et al., 1970). Perhaps, due to these reasons, after spawning, in the gonads of female bream, the amount of dry matter increased, including lipids and protein.

By the end of the feeding period, in the muscles of bream, the content of dry matter increased, including lipids, protein and ash (Tables 3, 4). In the liver of males and females, the amount of total moisture, lipids and protein decreased, ash and nitrogen-free extracts increased. In the gonads of bream, increase in the content of lipids, protein and carbohydrates was determined. Products of metabolism in this period can accumulate in the muscular tissues of bream due to intensive feeding of fish because of the optimum temperatures (Shatunovskii, 1980; Aidos et al., 2002; Tzikas et al., 2007). High content of lipids in the muscles and organs of female bream, accumulation in the feeding period, are the energy reservoir that allows the individuals to be prepared for wintering and spawning (HtunHa, 1978; Tzikas et al., 2007). In the liver, the content of lipids and proteins decreased, whereas in the gonads these parameters increased (Table 3, 4). Decrease in the total amount of lipids in the liver of bream in the autumn period could be related to the fact that the development of the gonads requires a large and easily-acceptable source of energy (Craig et al., 2000). Increase in the level of nitrogen-free extracts in the liver could indicate non-favourable conditions of feeding in the feeding period, because with intake of nutrients, the organ accumulates glycogen (Viegas et al., 2012). It should be noted that the indices of the organs in females in this period were lower than after spawning (Table 2). Decrease in the gonadosomatic index in females in autumn could be attributed to the fact that the remaining small part of eggs dissolved into fat in the cavity, and decrease in the hepatosomatic index - to transportation of part of nutrients from the 
liver to the gonads (Pravdin, 1966). Perhaps, in bream, as well as pike, mass of the liver and the content of nutrients in it are to a larger degree associated with the development of the gonads rather than the intensity of feeding (Medford \& Mackay, 1978).

Besides the seasonal dynamics of biochemical changes in the muscles and the liver of bream, it is interesting to analyze the relationship of fatness of individuals with the content of the products of metabolism in their body. The literature contains data on decrease in the fatness coefficient of fish both during spawning and the period of feeding (Mello \& Rose, 2005; Grigorjev, 2007). In our study, the value of fatness coefficient was the highest in the post-spawning period, at the same time in the muscles of male and female bream in that period, a high share of total moisture and low content of lipids and protein was seen (Tables 2-4). In addition, in the end of the feeding period, the fatness of bream decreased to the minimum values, whereas the amount of protein and lipids in the muscular tissue increased. The higher the amount of moisture in fish, the lower the quantity of proteins and lipids which it replaces during energy expenditures of the organism in the period of spawning and after wintering (Dawson \& Grimm, 1980; Flath \& Diana, 1985; Ali et al., 2005). The specific weight of lipids was lower than that of moisture, therefore their replacement with water may lead to increase in the mass of fish (Shulman \& Love, 1999). Thus, weight of individuals, and therefore their fatness increased due to increase in the water content in the muscles, indicated by positive correlation between the fatness coefficient according to Clark and the amount of the total moisture in the muscles ( 0.50 in males and 0.95 in females).

\section{Conclusions}

The results obtained on the peculiarities of the accumulation of the products of metabolism in the muscular tissue and the organs of bream allowed us to determine some peculiarities which characterize the metabolic processes occurring in this species in certain periods of the yearly cycle. Metabolism in males and females during feeding and maturation of the gonads takes its course with different intensity. In male bream, the energy expenditures were more manifested after wintering, whereas in females during spawning. The main energy reserve in the form of lipids in the annual cycle changes more significantly in the organism of male bream, and at the same time increased content of fat in the muscular tissue of males in May suggests their better preparation for spawning compared with females. The maturation of the gonads of females requires more metabolic products than in males, therefore during each period of the annual cycle, the ovaries contain more protein than in the testes. Nonetheless, male bream were observed to have increased energy expenditures related to the reproductive behaviour in the period of spawning, thus the total energy contribution to the reproduction may be the same both for females and males. The expenditures of nutrients in the annual cycle of bream in the liver were determined to be higher than in the muscular tissue, indicating use of the liver rather than the muscles as the energy "depot". At the same time, the liver and the muscular tissue in the organism of bream can be the source of energy during the deficiency of food and during spawning. Due to replacement of lipids with water, the specific weight of which can exceed the weight of lipids, mass of fish, and therefore and fatness of bream increased due to rise in the moisture content in the muscles.

The authors express their sincere gratitude to their colleagues in the Laboratory of Fish Ecology of the Papanin Institute for Biology of Inland Waters Russian Academy of Sciences for their help in collecting material and identification of the age of the fish. They also wish to thank Y. V. Gerasimov, D. P. Kabanov, M. I. Bazarov, D. D. Pavlov, M. I. Malin and A. A. Bolotovsky (Papanin Institute for Biology of Inland Waters Russian Academy of Sciences) for their help in processing the material.

Financial support: Russian Ministry of Science and Higher Education, Project No 0856-2020-0008.

\section{References}

Adams, S. M., McLean, R. B., \& Parrotta, J. A. (1982). Energy partitioning in largemouth bass under conditions of seasonally fluctuating prey availability. Transactions of the American Fisheries Society, 111(5), 549-558.
Aidos, I., van der Padt, A., Luten, J. B., \& Boom, R. M. (2002). Seasonal changes in crude and lipid composition of herring fillets, byproducts, and respective produced oils. Journal of Agricultural and Food Chemistry, 50(16), 4589-4599.

Ali, M., Iqbal, F., Salam, A., Iram, S., \& Athar, M. (2005). Comparative study of body composition of different fish species from brackish water pond. International Journal of Environmental Science and Technology, 2(3), 229-232.

Bilokon, G. S., Marenkov, O. M., \& Dvoretskiy, A. I. (2013). Contents of radionuclides and heavy metals in fish roe of commercial fish of the Zaporizhya Reservoir. Nuclear Physics and Atomic Energy, 14(1), 81-85.

Brodersen, J., Hansen, J. H., \& Skov, C. (2019). Partial nomadism in large-bodied bream (Abramis brama). Ecology of Freshwater Fish, 28(4), 650-660.

Carter, C. G., \& Houlihan, D. F. (2001). Protein synthesis. Fish Physiology, 20, 31-75.

Craig, J. F. (1977). The body composition of adult perch, Perca fluviatilis in Windermere, with reference to seasonal changes and reproduction. Journal of Animal Ecology, 46(2), 617-632.

Craig, S. R., MacKenzie, D. S., Jones, G., \& Gatlin III, D. M. (2000). Seasonal changes in the reproductive condition and body composition of free-ranging red drum, Sciaenops ocellatus. Aquaculture, 190, 89-102.

Dabhade, V. F., Pathan, T. S., Shinde, S. E., Bhandare, R. Y., \& Sonawane, D. L. (2009). Seasonal variations of protein in the ovary of fish Channa gachua. Recent Research in Science and Technology, 1(2), 78-80.

Dawson, A. S., \& Grimm, A. S. (1980). Quantitative seasonal changes in the protein, lipid and energy content of the carcass, ovaries and liver of adult female plaice, Pleuronectes platessa L. Journal of Fish Biology, 16(5), 493-504.

Diamond, M. (1985). Some observations of spawning by roach, Rutilus rutilus L., and bream, Abramis brama L., and their implications for management. Aquaculture Research, 16(4), 359-367.

Diana, J. S., \& Mackay, W. C. (1979). Timing and magnitude of energy deposition and loss in the body, liver, and gonads of northern pike (Esox lucius). Journal of the Fisheries Board of Canada, 36(5), 481-487.

Ding, H., Zhang, Z., Xie, C., Liu, C., Chen, F., Huang, D., Li, Z., \& Chen, Y. (2019). An assessment of European bream Abramis brama (Linnaeus, 1758) fishery in the downstream of the Irtysh River in China. Journal of Freshwater Ecology, 34(1), 107-122.

do Carmo Silva, J. P., da Costa, M. R., \& Araújo, F. G. (2019). Energy acquisition and allocation to the gonadal development of Cynoscion leiachus (Perciformes, Sciaenidae) in a tropical Brazilian bay. Marine Biology Research, 15(2), 170-180.

Flath, L. E., \& Diana, J. S. (1985). Seasonal energy dynamics of the alewife in southeastern Lake Michigan. Transactions of the American Fisheries Society, 114(3), 328-337.

Flerova, E. A. (2014). Fiziologo-biohimicheskie metody issledovaniya ryb [Physiological and biochemical methods for the study of fish]. Izdatel'stvo Yaroslavl State Agricultural Academy, Yaroslavl (in Russian).

German, A. V. (2019). Disturbance of synchronous oocyte development in bream Abramis brama L. from the Rybinsk Reservoir. Inland Water Biology, 12(1), $128-131$.

Gorbatenko, K. M., \& Lazhentsev, A. E. (2016). The biochemical composition and calorie density of the walleye pollock Theragra chalcogramma in the Sea of Okhotsk. Russian Journal of Marine Biology, 42(7), 591-601.

Grande, M., Murua, H., Zudaire, I., Arsenault-Pernet, E. J., Pernet, F., \& Bodin, N. (2016). Energy allocation strategy of skipjack tuna Katsuwonus pelamis during their reproductive cycle. Journal of Fish Biology, 89(5), 2434-2448.

Grigorakis, K., Alexis, M. N., Taylor, K. A., \& Hole, M. (2002). Comparison of wild and cultured gilthead sea bream (Sparus aurata); composition, appearance and seasonal variations. International Journal of Food Science and Technology, 37(5), 477-484.

Grigorjev, V. N. (2007). Izmenenie pokazatelej rosta i koefficienta upitannosti gustery Blicca bjoerkna (Cyprinidae) v verhnej chasti Kujbyshevskogo vodohranilishcha $\mathrm{v}$ usloviyah transformacii ego ekosistemy [The growth parameters variability and weight-length relation indexes of white bream Blicca bjoerkna (Cyprinidae) in the upper Kuybyshev Reservoir in changing condition of its ecosystem]. Uchenye Zapiski Kazanskogo Universiteta, Seriya Estestvennye Nauki, 149(2), 69-74 (in Russian).

Guijarro, A. I., Lopez-Patiño, M. A., Pinillos, M. L., Isorna, E., De Pedro, N., Alonso-Gómez, A. L., Alonso-Bedate, M., \& Delgado, M. J. (2003). Seasonal changes in haematology and metabolic resources in the tench. Journal of Fish Biology, 62(4), 803-815.

Hiraoka, Y., Okochi, Y., Ohshimo, S., Shimose, T., Ashida, H., Sato, T., \& Ando, Y. (2019). Lipid and fatty acid dynamics by maternal Pacific bluefin tuna. PloS One, 14(9), 1-18.

Hossain, M. A., Al-Abdul-Elah, K., \& Yaseen, S. B. (2019). Seasonal variations in proximate and fatty acid composition of sobaity sea bream (Sparidentex hasta) in Kuwait waters. Journal of the Marine Biological Association of the United Kingdom, 99(4), 991-998.

Htun-Han, M. (1978). The reproductive biology of the dab Limanda limanda (L.) in the North Sea: Gonosomatic index, hepatosomatic index and condition factor. Journal of Fish Biology, 13(3), 369-378. 
Ilmast, N. V. (2005). Vvedenie v ihtiologiyu [Introduction to Ichthyology]. Karelian Research Center of the Russian Academy of Sciences, Petrozavodsk (in Russian).

Islam, M. N., \& Joadder, M. A. R. (2005). Seasonal variation of the proximate composition of freshwater Gobi, Glossogobius giuris (Hamilton) from the River Padma. Pakistan Journal of Biological Sciences, 8(4), 532-536.

Jan, U., Shah, M., Manzoor, T., \& Ganie, S. A. (2012). Seasonal and monthly variations of protein content in the muscle of fish Schizothorax esocinus. Recent Research in Science and Technology, 4(7), 5-7.

John Kiran, P., Annapurna, Y., Krishna, P., \& Sreeramulu, K. (2017). Seasonal variation of proximate composition of Istiophorus platypterus from Visakhapatnam fishing harbor, East Coast of India. International Journal of Bioassays, 6, 5530-5534.

Jøsrgensen, E. H., Johansen, S. J. S., \& Jobling, M. (1997). Seasonal patterns of growth, lipid deposition and lipid depletion in anadromous Arctic charr Journal of Fish Biology, 51(2), 312-326.

Karabanov, D. P., Pavlov, D. D., Bazarov, M. I., Borovikova, E. A., Smirnov, A. K., \& Stolbunov, I. A. (2018). Alien species of fish in the littoral of Volga and Kama reservoirs (results of complex expeditions of IBIW RAS in 20052017). Transactions of Papanin Institute for Biology of Inland Waters RAS, $82(85), 67-80$

Khalko, V. V. (2018). Sexual dimorphism of physiological and biochemical state of trunk muscle in bleak (Alburnus alburnus L.) (Cypriniformes, Cyprinidae) spawners of the Rybinsk Reservoir in the Prespawning Period. Inland Water Biology, 11(2), 214-218.

Komova, N. I., Chuiko, G. M., Morozov, A. A., \& Yurchenko, V. V. (2017). Reproductive parameters of roach Rutilus rutilus (L.) from the Rybinsk Reservoir reaches differing in anthropogenic loads. Inland Water Biology, 10(3), 296-300.

Kornienko, G. G., Dudkin, S. I., Sergeeva, S. G., Ruzhinskaya, L. P., Tsema, N. I., Bugaev, L. A., \& Voykina, A. V. (2017). Fiziologo-biohimicheskaya harakteristika ryb Azovo-Chernomorskogo bassejna v usloviyah sovremennoj antropogennoj nagruzki [Physiological and biochemical characteristics of the Azov and Black sea fishes undergoing anthropogenic pressure]. Bulletin of Kamchatka State Technical University, 40, 58-66 (in Russian).

Kosker, A. R., Ozogul, F., Durmus, M., Ucar, Y., Ozogul, Y., Boga, E., \& Ayas, D. (2018). Seasonal changes in proximate composition and mineral-heavy metal content of pufferfish (Lagocephalus sceleratus) from northeastern Mediterranean sea. Turkish Journal of Fisheries and Aquatic Sciences, 18(11), 1269-1278.

Kostić, J., Kolarević, S., Kračun-Kolarević, M., Aborgiba, M., Gačić, Z., Lenhardt, M., \& Vuković-Gačić, B. (2016). Genotoxicity assessment of the Danube River using tissues of freshwater bream (Abramis brama). Environmental Science and Pollution Research, 23(20), 20783-20795.

Kozlova, T. A. (1997). Seasonal cycles in total chemical composition of two Lake Baikal benthic-pelagic sculpins (Cottocomephorus, Cottoidei). Journal of Fish Biology, 50(4), 734-743.

Krivobok, M. N., \& Tarkovskaya, O. I. (1960). Opredelenie srokov nerestovyh migracij salaki na osnovanii izucheniya ee zhirovogo obmena [Determining the timing of spawning migrations of herring based on the study of its fat metabolism]. VNIRO Proceedings, 42, 171-188 (in Russian).

Kumar, M., Varghese, T., Sahu, N. P., Gupta, G., \& Dasgupta, S. (2019). Changes in the biochemical and mineral composition of hilsa shad, Tenualosa ilisha (Hamilton, 1822) during upstream spawning migration. International Journal of Current Microbiology and Applied Sciences, 8(6), 338-346.

Lloret, J., Shulman, G. E., \& Love, R. M. (2014). Condition and health indicators of exploited marine fishes. Wiley-Blackwell.

Marenkov, O. N. (2018). Ecological and biological aspects of zander and Volga zander reproduction under conditions of the Zaporizhzhia reservoir (Ukraine). Ukrainian Journal of Ecology, 8(1), 441-450.

Matondo, B. N., Ovidio, M., Philippart, J. C., \& Poncin, P. (2009). Hybridization behaviour between two common European cyprinid fish species - silver bream, Blicca bjoerkna and common bream, Abramis brama - in a controlled environment. Animal Biology, 59(1), 97-108.

Medford, B. A., \& Mackay, W. C. (1978). Protein and lipid content of gonads, liver, and muscle of northern pike (Esox lucius) in relation to gonad growth. Journal of the Fisheries Research Board of Canada, 35(2), 213-219.

Mello, L. G. S., \& Rose, G. A. (2005). Seasonal cycles in weight and condition in Atlantic cod (Gadus morhua L.) in relation to fisheries. ICES Journal of Marine Science, 62(5), 1006-1015.

Mikryakov, V. R., Gudkov, D. I., Mikryakov, D. V., Pomortseva, N. L., \& Balabanova, L. V. (2013). Comparative characteristics of leucocytes compositions in the crucian carp Carassius carassius (Cyprinidae) from the waterbodies of the Chernobyl exclusion zone and from the Rybinsk reservoir. Journal of Ichthyology, 53(9), 753-757.

Munakata, A., \& Kobayashi, M. (2010). Endocrine control of sexual behavior in teleost fish. General and Comparative Endocrinology, 165(3), 456-468.

Parrish, C. C. (1999). Determination of total lipid, lipid classes, and fatty acids in aquatic samples. In: Arts, M. T., \& Wainman, B. C. (Eds.). Lipids in freshwater ecosystems. Springer. Pp. 4-20.
Payuta, A. A., \& Flerova, E. A. (2019). Some indicators of metabolism in the muscles, liver, and gonads of pike-perch Sander lucioperca and sichel Pelecus cultratus from the Gorky Reservoir. Joumal of Ichthyology, 59(2), 255-262.

Petenuci, M. E., Rocha, I. D. N. A., de Sousa, S. C., Schneider, V. V. A., da Costa, L. A. M. A., \& Visentainer, J. V. (2016). Seasonal variations in lipid content, fatty acid composition and nutritional profiles of five freshwater fish from the Amazon basin. Journal of the American Oil Chemists' Society, 93(10), 1373-1381.

Plack, P. A., Pritchard, D. J., \& Fraser, N. W. (1971). Egg proteins in cod serum. Natural occurrence and induction by injections of oestradiol 3-benzoate. Biochemical Journal, 121(5), 847-856.

Poncin, P., Matondo, B. N., Termol, C., Kestemont, P., \& Philippart, J. C. (2011) Relationships between circulating androgens, aggressive behaviour and breeding tubercles in males of the common bream Abramis brama L. in an aquarium environment. Fish Physiology and Biochemistry, 37(3), 533-542.

Pradhan, S. C., Patra, A. K., \& Pal, A. (2015). Seasonal analysis of the biochemical composition of muscle and liver of Catla catla in a tropical climate of India. Comparative Clinical Pathology, 24(3), 593-603.

Pravdin, I. F. (1966). Rukovodstvo po izucheniyu ryb [Fish study guide]. Pishchevaya Promyshlennost', Moscow (in Russian).

Rajasilta, M. (1992). Relationship between food, fat, sexual maturation, and spawning time of Baltic herring (Clupea harengus membras) in the Archipelago Sea. Canadian Journal of Fisheries and Aquatic Sciences, 49(4), 644-654.

Rao, A. C., \& Krishnan, L. (2011). Biochemical composition and changes in biological indices associated with maturation of the ovary in the spiny cheek grouper Epinephelus diacanthus (Valenciennes, 1828). Indian Journal of Fisheries, 58(2), 45-52.

Romotowska, P. E., Karlsdóttir, M. G., Gudjónsdóttir, M., Kristinsson, H. G., \& Arason, S. (2016). Seasonal and geographical variation in chemical composition and lipid stability of Atlantic mackerel (Scomber scombrus) caught in Icelandic waters. Journal of Food Composition and Analysis, 49, 9-18.

Shankar, D. S., \& Kulkarni, R. S. (2006). Effect of cortisol on female freshwater fish Notopterus notopterus. Journal of Environmental Biology, 27(4), 727-731.

Shatunovskii, M. I. (1980). Ekologicheskie zakonomernosti obmena veshchestv morskih ryb [Ecological patterns of metabolism of marine fish]. Nauka, Moscow (in Russian).

Shreni, K. D. (1980). Seasonal variations in the chemical composition of the catfish, Heteropneustes fossilis (Bloch). Proceedings - Animal Sciences, 89(2), 191-196.

Shulman, G. E., \& Love, R. M. (1999). The biochemical ecology of marine fishes. Volume 36. Academic Press.

Shulman, G. E., Revina, N. I., \& Safyanova, T. E. (1970). Svyaz’ fiziologicheskogo sostoyaniya s osobennostyami ovogeneza pelagicheskih ryb [The relationship of the physiological state with the peculiarities of ovogenesis of pelagic fish]. VNIRO Proceedings, 69, 96-108 (in Russian)

Smith, C. \& Wootton, R. J. (2016). The remarkable reproductive diversity of teleost fishes. Fish and Fisheries, 17(4), 1208-1215.

Soyano, K., \& Mushirobira, Y. (2018). The mechanism of low-temperature tolerance in fish. In: Iwaya-Inoue, M., Sakurai, M., \& Uemura, M. (Eds.) Survival strategies in extreme cold and desiccation. Springer. Pp. 149-164.

Sutharshiny, S., Sivashanthini, K., \& Thulasitha, W. S. (2013). Lipid changes in relation to maturation and spawning of tropical double spotted queenfish, Scomberoides lysan (Forsskål, 1775). Asian Journal of Animal and Veterinary Advances, 8(4), 555-570.

Turdakov, A. F. (1972). Vosproizvoditel'naya sistema samcov ryb [Reproductive system of male fish]. Ilim, Frunze (in Russian).

Tyheev, A. A., \& Tomitova, E. A. (2016). Morfologicheskaya kartina gonad samok plotvy v osennij period v Istominskom soru Kabanskogo rajona Respubliki Buryatiya [Morphological image of gonads of roach females during the autumn period inthe Istominsky sorof the Kabansky district of the Rebublic of Buryatia]. Vestnik IrGSHA, 74, 62-70 (in Russian).

Tzikas, Z., Amvrosiadis, I., Soultos, N., \& Georgakis, S. (2007). Seasonal variation in the chemical composition and microbiological condition of Mediterranean horse mackerel (Trachurus mediterraneus) muscle from the North Aegean Sea (Greece). Food Control, 18(3), 251-257.

Varkentin, A. I. (2015). Sezonnaya dinamika zrelosti gonad i pokazatelej upitannosti mintaya (Theragra chalcogramma) v severnoj chasti Ohotskogo morya [Seasonal dynamics of gonads maturity and indices of body condition for walleye pollock Theragra chalcogramma in the northern part of the Okhotsk Sea]. Izvestia TINRO, 180, 77-92 (in Russian).

Venkatesan, V., Gandhi, V., \& Zacharia, P. U. (2013). Observations on the utilization of the biochemical constituents during maturation of the butterfish $\mathrm{Sca}$ tophagus argus (L. 1766) from Palk Bay, south east coast of India. Indian Journal of Geo-Marine Sciences, 42(1), 75-81.

Viegas, I., de Albuquerque Carvalho, R., Pardal, M. Â., \& Jones, J. G. (2012). Advances and applications of tracer measurements of carbohydrate metabolism in fish. In: Türker, H. (Ed.). New advances and contributions to fish biology. Intech Open.

Wallace, R. A., \& Selman, K. (1981). Cellular and dynamic aspects of oocyte growth in teleosts. American Zoologist, 21(2), 325-343. 
Wootton, R. J. (1974). The inter-spawning interval of the female three-spined stickleback, Gasterosteus aculeatus. Journal of Zoology, 172(3), 331-342.

Wootton, R. J. (1985). Energetics of reproduction. In: Tytler, P., \& Calow, P. (Eds.). Fish energetics. Springer. Pp. 231-254.

Wootton, R. J., \& Smith, C. (2015). Reproductive biology of teleost fishes. John Wiley \& Sons.

Yeannes, M. I., \& Almandos, M. E. (2003). Estimation of fish proximate composition starting from water content. Journal of Food Composition and Analysis, 16(1), 81-92.

Yeganeh, S., Shabanpour, B., Hosseini, H., Imanpour, M. R., \& Shabani, A. (2012). Comparison of farmed and wild common carp (Cyprinus carpio): Seasonal variations in chemical composition and fatty acid profile. Czech Journal of Food Sciences, 30(6), 503-511.
Zaboukas, N., Miliou, H., Megalofonou, P., \& Moraitou-Apostolopoulou, M. (2006). Biochemical composition of the Atlantic bonito Sarda sarda from the Aegean Sea (Eastern Mediterranean Sea) in different stages of sexual maturity. Journal of Fish Biology, 69(2), 347-362.

Žák, J., Prchalová, M., Šmejkal, M., Blabolil, P., Vašek, M., Matěna, J., Ř́ha, M., Peterka, J., Sed'a, J., \& Kubečka, J. (2020). Sexual segregation in European cyprinids: Consequence of response to predation risk influenced by sexual size dimorphism. Hydrobiologia, 847(6), 1439-1451.

Zarubin, O. L., Zarubina, N. E., Kostyuk, V. A., Malyuk, I. A., Gudkov, D. I., Volkova, E. N., Belyaev, V. V., Kaglyan, A. E., Nazarov, A. B., Belokon, A. S., \& Marenkov, O. N. (2013). Specific activity ${ }^{137} \mathrm{Cs}$ at fishes of Ukraine. Current state. Nuclear Physics and Atomic Energy, 14(2), 177-182.

Zorica, B., Anđelić, I., \& Keč, V. Č. (2019). Sardine (Sardina pilchardus) spawning in the light of fat content analysis. Scientia Marina, 83(3), 207-213. 